\title{
Saline Water Intrusion in Coastal Aquifers: A Case Study from Bangladesh
}

\author{
Dr. Md. Mizanur Rahman, Dr. Amartya Kumar Bhattacharya \\ Post-Doctoral Research Fellow, Nipissing University, 100 College Drive, Box 5002, North Bay, Ontario 18 \\ 8L7, CANADA. \\ Professor, Department of Applied Mechanics, Bengal Engineering and Science University, Shibpur \\ Howrah - 711103, West Bengal, INDIA.
}

\begin{abstract}
The magnitude of salinity intrusion in coastal areas depends on sensible balance between fresh water flow and saltwater from the sea. The interface between freshwater and saline water is influenced by geology, hydrogeology, ground water heads and groundwater well pumping rates. But fresh water is important issue to counterbalance salinity intrusion at the upstream water intake. To quantify that required fresh water, indeed detailed understanding of the physical phenomena (tidal motion, wind mixing etc, river flow) is a prerequisite. The coastal zone of Bangladesh comprises of part of the flat Ganga Delta, which is crisscrossed by large tidal rivers discharging into the Bay of Bengal. The estuaries and tidal river systems of coastal zone have been formed by long periodical deltaic accretion which was dominated by the historical morphological changes of Ganga and Brahmaputra. The major estuarial rivers of the south-central region are interlinked and fed by numerous smaller channels. The approximate population in the coastal area is 40 million and they are very much vulnerable to the natural disaster along the about $720 \mathrm{~km}$ coastline. Saline water intrusion is the main problem in the south-western zone. About 60 and 15 percent of arable land (total 1.0 mha croplands) of southwestern and southeastern respectively are affected by salinity in the dry period. This salinity is caused by cyclone and storm surges, high spring tide inundation and capillary actions. Its affect the soil surface and root zones, which decreases the crop production about 0.13 M.T. in every year. The increase of salinity intrusion and decrease of arability will be prevailing due to climate change effect and reducing of flood plain and it may propagate in all over the country. In this situation management of salinity intrusion is the vital issue for Bangladesh. With the mission of saline water proofing by structural management like coastal embankment projects, dam, sluices etc and coastal area zoning as non-structural management to change the land use and other activities can be the vision of sustainable livelihood and environment of Bangladesh.
\end{abstract}

\section{INTRODUCTION}

The movement of saline water into a freshwater aquifer or surface reservoir is known as saltwater intrusion and if the source of this saline water is sea water, then this process is known as seawater intrusion. Freshwater is slightly less dense (lighter) than saltwater, which tends it to float on top of the saltwater when both fluids are present in an aquifer. The relationship based on the density difference between saltwater and freshwater is used to estimate the depth to saltwater based on the thickness of the freshwater zone above sea level. The relationship is known as the Ghyben-Herzberg relation (Figure 1). In the coastal area of Bangladesh, hydro-geological conditions vary considerably even within short distances. Ground water, with gradient about 1:20000, flows from north to south having localised outflow into rivers and ponds in dry season and inflow into the aquifer from surface water sources in the rainy season. Transmissivities of the main aquifer in the coastal area ranges from $250 \mathrm{~m} 2 /$ day to $10000 \mathrm{~m} 2 /$ day with an average value of $1000 \mathrm{~m} 2 /$ day. The storage capacity of the aquifer generally increases with depth with the increase in the size of aquifer materials. The entire area is underlain by thick water bearing formations of varying depths and the regional hydrogeology is very complex (Ahmed, 1996). Shamsuddin (1986) observed that the salinity distributions in Khulna, Barisal and Patuakhali regions were not in agreement with the Ghyben-Herzberg theory.

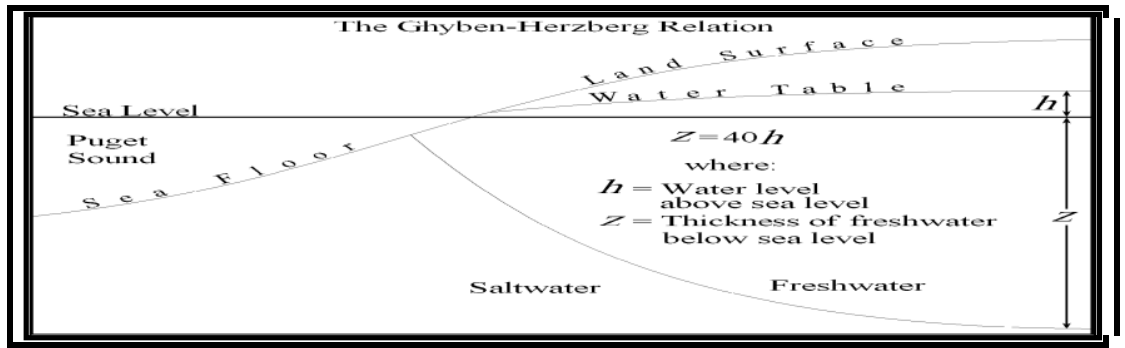

Figure 1: Ghyben-Herzberg relation 
An example sketch is given in Figure 2 showing aquifers and aquitards which vary spatially in both thickness and elevation. There may be several aquifers present, and each aquifer will have different hydraulic characteristics (recharge, pressure, capacity etc) and susceptibility to seawater intrusion. The hydraulic characteristics can vary significantly from one location to another even within a single aquifer. This variability and complexity of our groundwater system makes uncertainty to solve adverse situation in it. As a result, water resource planning and management efforts have primarily relied on review of water use proposals on an individual basis.

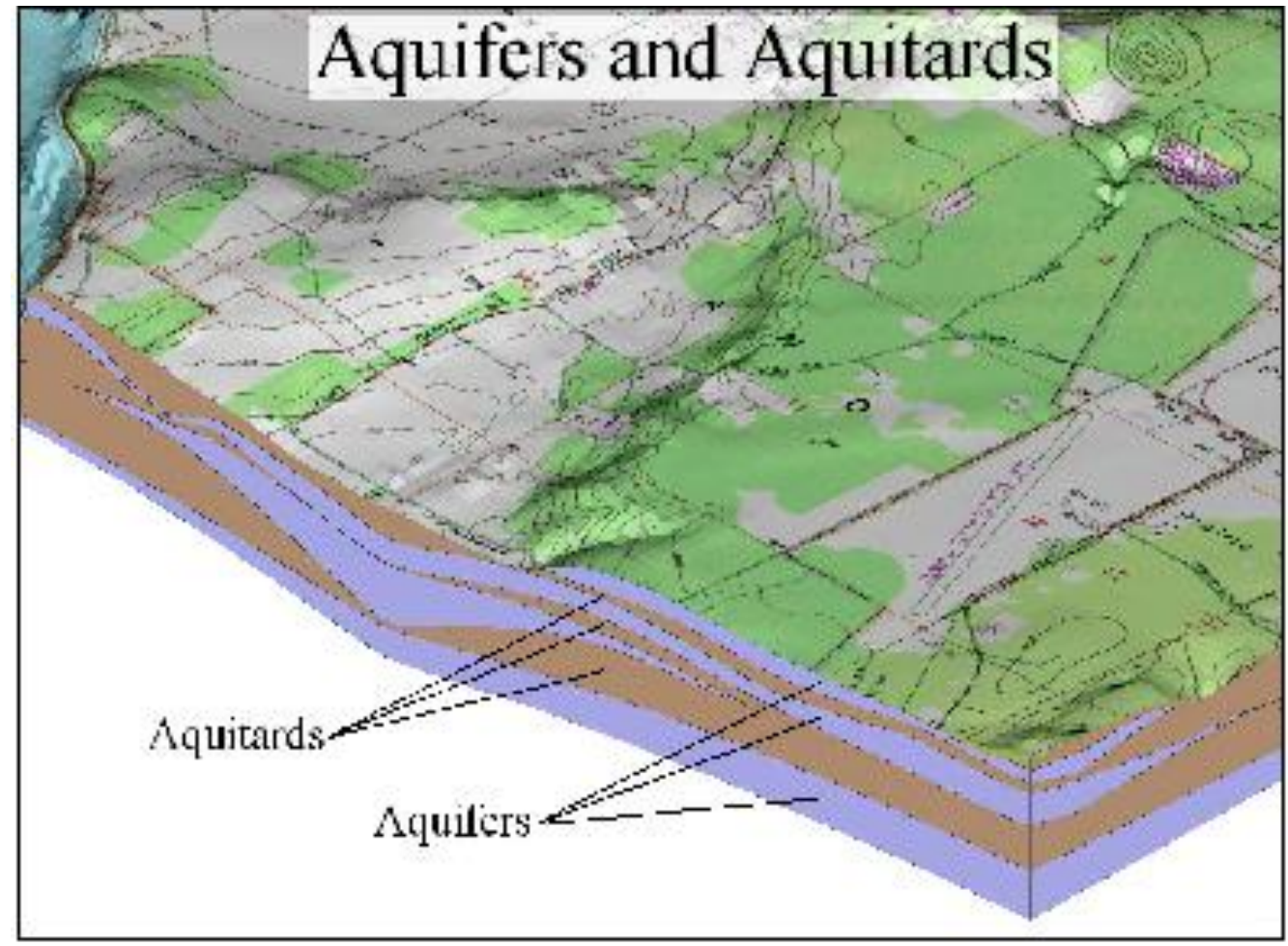

Figure 2: Example of Spatial variation of aquitards and aquifers

\section{GEOLOGY AND HYDROGEOLOGY OF BANGLADESH}

\section{(Ravenscroft and McArthur, 2004)}

Alluvial and deltaic sediments of the Ganga, Brahmaputra and Meghna rivers build the Bengal Basin the eastern part of which is Bangladesh (Morgan and McIntire, 1959). The north-south section in Fig. 3 provides a generalized description of the aquifers in the coastal zone of Bangladesh (Fig. 4). The basin was dissected and infilled many times by the major rivers during Pleistocene times leading up to the last glacial maximum (LGM) at $18 \mathrm{ka} \mathrm{BP}(\mathrm{ka} \mathrm{BP}=$ thousands years before present, that is before $1950 \mathrm{AD}$ ) when sea level stood some 130 m lower than present (Umitsu, 1993; Kudrass et al., 1999; Goodbred and Kuehl, 2000). The flooded coastal plain and incised channels of Bangladesh were rapidly filled by estuarine, deltaic and alluvial sediments in the latest Pleistocene/Holocene transgression. The sediments that fill the accommodation space created by these incised channels have distinctly different hydraulic and geochemical properties from those inter-fluvial sediments (e.g., Barind and Madhupur Tracts) that predate them (BADC, 1992; Ravenscroft, 2003). Inter-fluvial sediments increasingly contain Cl'rich brackish water towards the coast (Hoque et al., 2003). The post-LGM valley-fill sediments are uncemented dark grey sands containing groundwater that is reducing and sometimes methanogenic (Ahmed et al., 1998), high in Fe and As (DPHE, 1999; Nickson et al., 1998, 2000; McArthur et al., 2001). The interfluvial and underlying sediments that predate the LGM are formed by oxidized, often brown-coloured, sands of lower average permeability (MPO, 1987; BADC, 1992). The aquifer sands are fine-to-medium grained with typical hydraulic conductivities of $10-50 \mathrm{~m} / \mathrm{d}$ which contain water that is less reducing, low in $\mathrm{Fe}$ and As, and is generally less mineralized (Ravenscroft, 2003). In between aquitards are more prominent in the southwards and normally contain brackish groundwater. The brackish water is connate, and has locally leaked into underlying sands (Hoque et al., 2003). As the aquifers become more strongly confined, the waters tend to become more reducing and higher in Fe (Rus, 1985). 


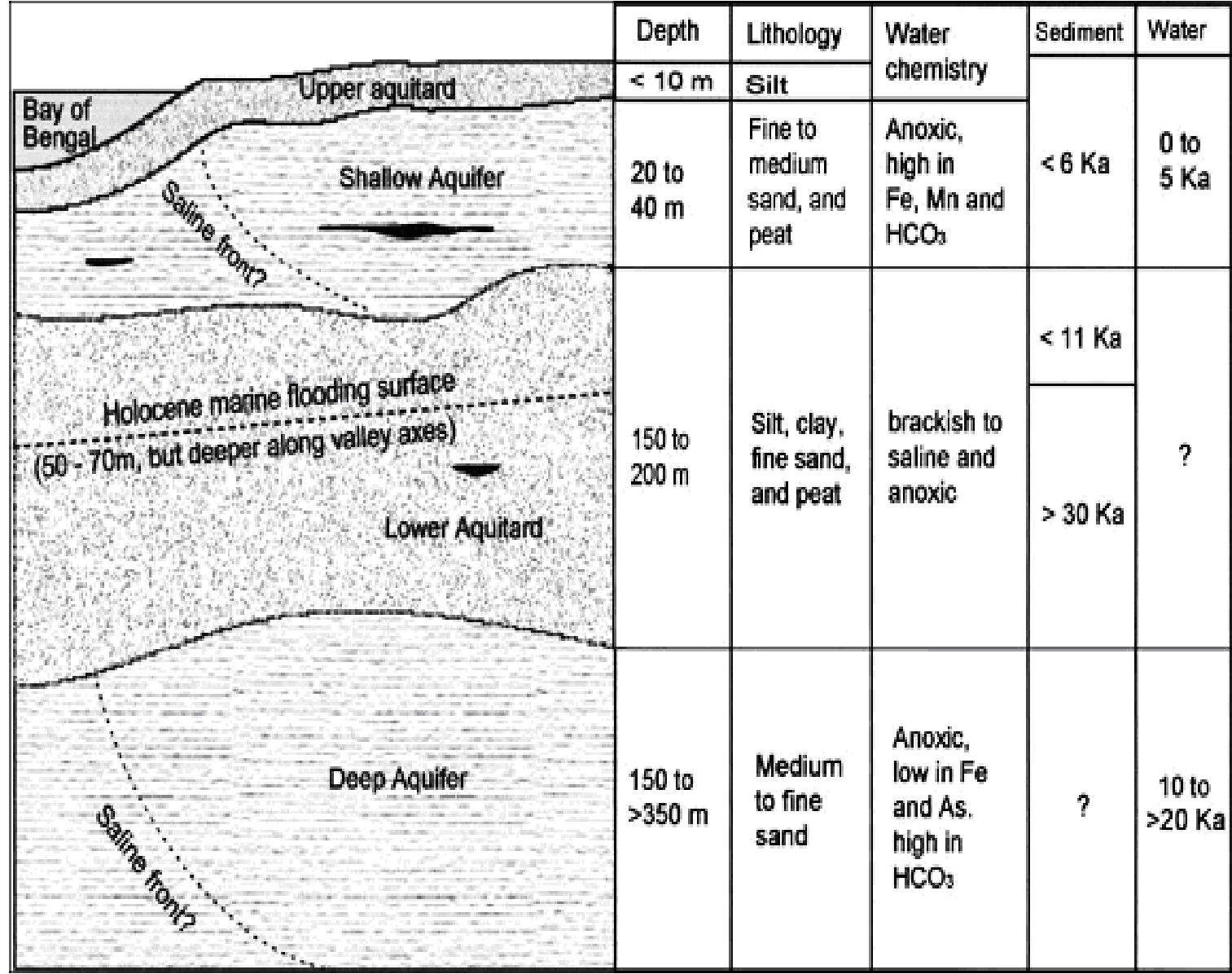

Figure. 3. Schematic of aquifer stratigraphy in the coastal zone of Bangladesh (Ravenscroft and McArthur, 2004)

Pliocene to Holocene sediments are extensively tapped to supply drinking water and the majority of irrigation and industrial supplies (MPO, 1987). The deep coastal aquifers are not used for irrigation because of high cost of wells $>200 \mathrm{~m}$ deep. Aquifers below about $150 \mathrm{~m}$ have been intensively pumped for municipal supply over a period of 20-30 a at towns such as Khulna, Barisal and Noakhali, and as yet have not been significantly affected by salinisation (LGED, 1994), despite claims to the contrary (Hassan et al., 1998; Rahman et al., 2000).

\section{a. SALINITY PROCESSES IN BANGLADESH}

For the deposition of silt and clay, the spatial distribution and concentrations of salinity in the estuary are important in the delta formation. The intrusion of saline water towards inland determines its suitability for drinking, irrigation and other purposes. During the wet season, vertical variation of salinity may play a role in the seasonal storage of sediment at the outside of the estuary.

Because of shallow depth, the Meghna Estuary is generally a well-mixed estuary where the salinity is constant in a vertical water column (BWDB et al, 1998). During the monsoon, Land Reclamation Project (LRP) and Meghna Estuary Survey (MES) measured that an approximately $100 \mathrm{~km}$ long zone (Kutubdia-Sandwip) develops in the southeastern part of the estuary where vertical variation occurs where a layer of brackish water moves with the tide in the form of a salt wedge. The general concept is that during the dry season, part of the sediment is brought back into the estuary through a so-called tidal pumping process, and deposited there (BWDB et al, 1998). 


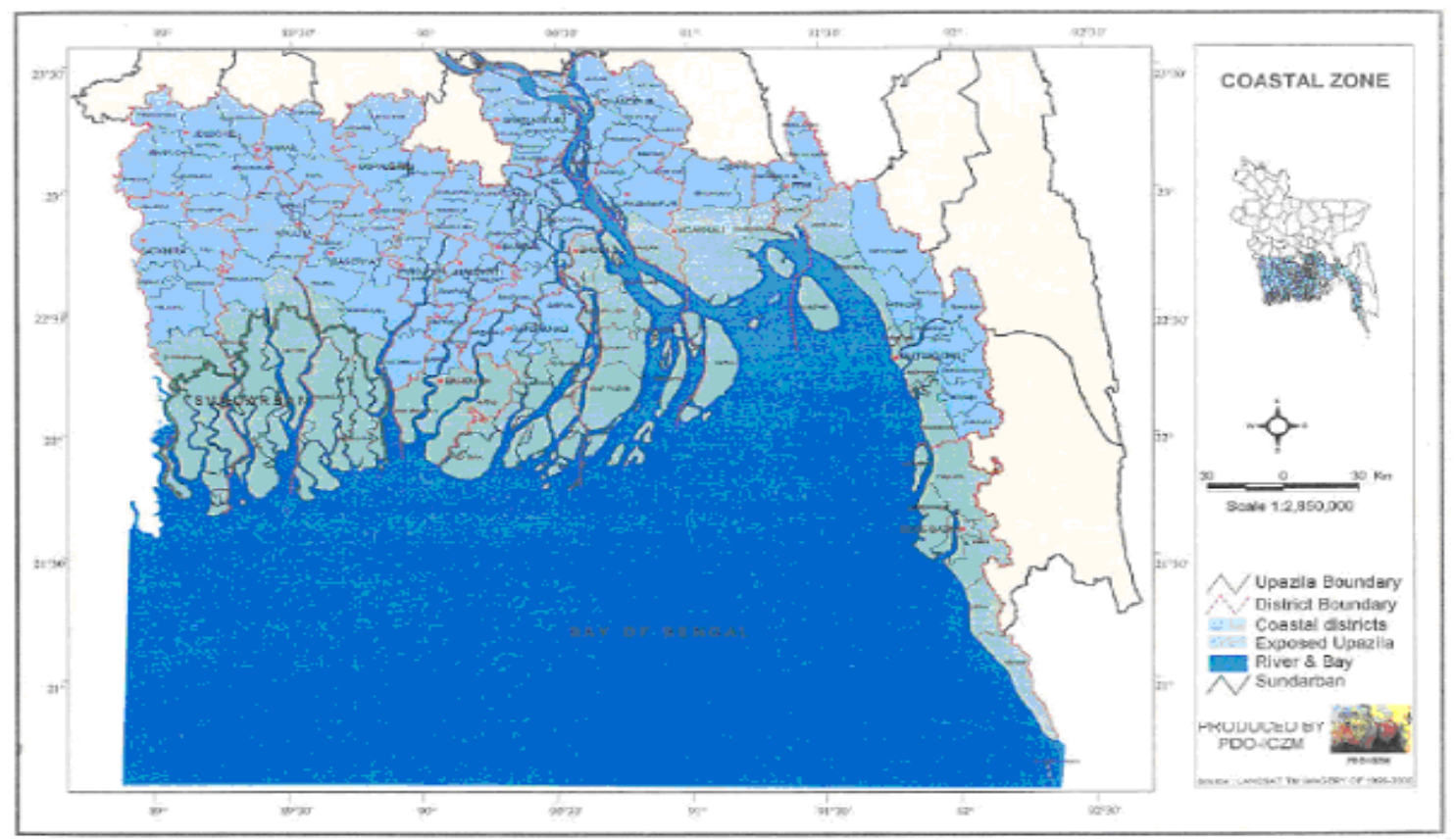

Figure 4: Coastal Zone of Bangladesh (PDO-ICZM, 2002)

In the coastal area of Bangladesh salinity increases during minimum river discharges but never exceeds seawater salinity (34 ppt). Intrusion of saline water during dry season is up to Char Gazaria where salinities less than 1 ppt. Salinity intrusion can increase either due to a decrease of fresh water flow in the Lower Meghna River during the dry season, or due to further penetration of tide into the river system. Intrusion may be aggravated by upstream withdrawal of water and reducing size of floodplains, or by climate changes like decrease in dry season rainfall and sea level rise.

The surface water and soil salinity of coastal districts is shown in Table 1. In Khulna district salinity creates problems to agricultural production and affects the supply of clean water for industrial use. Same problem also exists in Chittagong when there are no releases from Kaptai Lake. The augmentation of salt water in the surface waters increases the abstraction of groundwater which then becomes vulnerable to a risk that salt water will be drawn into the aquifer.

Table 1: Salinity levels in ppm (SRDI, 2001)

\begin{tabular}{||l|r|r|r|}
\hline \multicolumn{1}{|c|}{ District } & Surface water & Soil & $4->15$ \\
\hline Bagerhat & $5->10$ & $4->15$ \\
\hline Barguna & $1-5$ & $0-4$ \\
\hline Barisal & 0 & $4->15$ \\
\hline Bhola & $1-10$ & 0 \\
\hline Chandpur & $<1$ & $0-8$ \\
\hline Chittagong & $0-<1$ & $>15$ \\
\hline Cox's Bazar & $<1$ & $0-15$ \\
\hline Feni & $0-10$ & $0-15$ \\
\hline Gopalganj & $<1$ & $4-8$ \\
\hline Jessore & $<1$ & $4-8$ \\
\hline Jhalokati & $<1$ & $8->15$ \\
\hline Khulna & $5->10$ & $4-8$ \\
\hline Lakshmipur & $<1$ & $<4-8$ \\
\hline Narail & 0 & $0->15$ \\
\hline Noakhali & $<1-10$ & $8->15$ \\
\hline Patuakhali & $1-10$ & $0-15$ \\
\hline Pirojpur & $0-10$ & $4-<15$ \\
\hline Satkhira & $5-<10$ & 0 \\
\hline Shariatpur & $<1$ & \multicolumn{2}{c}{} \\
\hline
\end{tabular}

Source: SRDI, 2001. 


\section{SALINITY MANAGEMENT ASPECTS IN BANGLADESH}

Salinity are not limited to economic activities, like agricultural crops production, fish and shrimp, and availability of water suitable for agriculture and industrial uses. River water salinity has also important implications for the natural environment, such as functioning of the Sundarban ecosystem, sedimentation rates in tidal rivers, and human health. Human health is especially influenced by sole dependence on saline water for domestic purposes (BWDB et al, 1998). The coastal zone ground water aquifer is contaminated with salt above permissible levels at various places. In Bangladesh, the official permissible threshold level of salt in groundwater is $600 \mathrm{mg} / \mathrm{l}$ chloride solution, which is higher than elsewhere. But for the coastal districts, due to the unavailability of good water, the permissible level is set at $1,000 \mathrm{mg} / \mathrm{l}$.

\section{Coastal Embankment Project}

Coastal Embankments were implemented in the early 60s as structural measure to prevent salt-water intrusion only for agricultural production. In the period of eightieth decade these were rehabilitated providing facilities of salt water intrusion by facilitating shrimp farming and salt cultivation. In that time these polders were considered for mangrove afforastation which also needs salt water in some extent.

The south-west of the Ganges (Ganga) Development Area of Bangladesh is saline. The southeast is relatively salt-free. The high salinity in the southwest allows production of salt water shrimps and is a key parameter that affects the species mix in the Sundarban. Salinity has also affected industrial use far inland. Some industries like Khulna Newsprint Mill are already being closed down. Figure 5 shows the time series of salt water increase in the southwest area of Bangladesh.

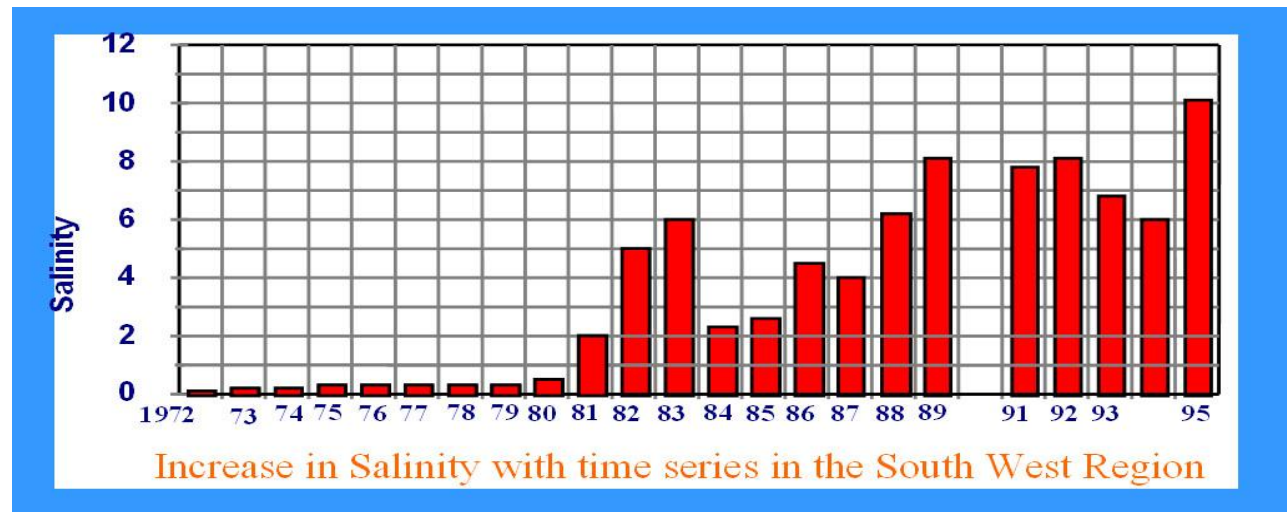

Figure 5: Increase in Salinity with respect to time in southwest Bangladesh

(http://www.sdnpbd.org/river_basin/bangladesh/bangladesh_salinity_intrusion.htm Dated 19.02.2006)

\section{Non-structural}

Large scale change in land use from long term plant species to perennials can be the solution to the increasing trends of salinity. A number of studies have demonstrated that increasing the area of perennial plants will have substantial negative effects on stream flow. Reducing of water for irrigation may increase the benefits of dry-land salinity. The management to areas of high groundwater salinity and soils is important by recharging. Different option scenarios may be developed for optimization of management of salinity. Sufficient understanding of catchment characteristics is important issue to ensure and consider the impact of salinity management on a range of natural resource objectives.

\section{CONCLUSION}

In Bangladesh salinity intrusion is time varying event and minimum during the monsoon (JuneOctober) by push back of the rivers discharge at the salinity front in estuarine and floodplains. It increases in inland coast from the month of November due to the reduction of fresh water flows and intrude up to $150 \mathrm{~km}$ inland in the lower Meghna in the South East and up to $290 \mathrm{~km}$ up the Passur River in the south-west of the country. Maximum salinity levels occur during March-April. The increase of salinity intrusion and decrease of arability will be prevailing due to climate change effect and reducing of flood plain. Investigations indicate that one third of the country will be inundated by green house effect, which may propagate the saline water intrusion all over the country and the total trans-boundary sources of potable water in ground water aquifer will be affected because agriculture is the mainstay livelihood of highly dense population which requires huge ground water abstraction for irrigation purpose. In this situation management of salinity intrusion is the vital issue for Bangladesh. With the mission of saline water proofing by structural management like coastal embankment projects, dam, sluices etc and coastal area zoning as non-structural management to change the land use and other 
activities can be the vision of sustainable livelihood and environment of Bangladesh. Further study to formulate the optimistic model for proper management by different option scenarios is essentially needed.

\section{REFERENCES}

[1] Ahmed, F., 1996, Coastal water supply in Bangladesh, Reaching the Unchanged: Challenges For The $21^{\text {st }}$ Century, 22nd WEDC Conference, New Delhi, India.

[2] Ahmed, K.M., Hoque, M., Hasan, K., Ravenscroft, P., Chowdhury, L.R., 1998. Occurrence and origin of water well methane gas in Bangladesh. J. Geol. Soc. India 51, 697-708.

[3] BADC, 1992. Deep Tubewell II Project. Final Report. Mott MacDonald Ltd. and Hunting Technical Services. Report for Bangladesh Agricultural Development Corporation and Overseas Development Administration (UK).

[4] BWDB, DHV International, DDC, SWMC, 1998, Draft Master Plan, Volume 2: Morphological Processes

[5] DPHE, 1999. Groundwater Studies for Arsenic Contamination in Bangladesh. Final Report, Rapid Investigation Phase. Department of Public Health Engineering, Government of Bangladesh. Mott MacDonald and British Geological Survey.

[6] Goodbred, S.L., Kuehl, S.A., 2000. The significance of large sediment supply, active tectonics, and eustasy on margin sequence development: Late Quaternary stratigraphy and evolution of the GangesBrahmaputra delta. Sed. Geol. 133, 227-248.

[7] Hassan, M.Q., Rahman, M., Islam, M.S., Shamsad, S.Z.K.M., 1998. Effects of salinity on the hydrogeo-environment of Khulna city and Mongla Port area of Bangladesh. Dhaka Univ. J. Biol. Sci. 7, 113-127.

[8] Hoque, M., Hasan, M.K., Ravenscroft, P., 2003. Investigation of Groundwater Salinity and Gas Problems in Southeast Bangladesh. In: Rahman, A.A., Ravenscroft, P. (Eds.), Groundwater Resources and Development in Bangladesh. Bangladesh Centre for Advanced Studies, University Press Ltd, Dhaka.

[9] Kudrass, H.R., Spiess, V., Michels, M., Kottke, B., Khan, S.R., 1999. Transport processes, accumulation rates and a sediment budget for the submarine delta of the Ganges- Brahmaputra and the Swatch of No Ground, Bangladesh. International Seminar on the Quaternary Development and Coastal Hydrodynamics of the Ganges Delta in Bangladesh, Geological Survey of Bangladesh, Dhaka, September 20-21, 1999.

[10] LGED, 1994. Municipal Services Project. Interim Report, vol. 5: Khulna Water Supply. Mott MacDonald Ltd in association with Louis Berger International, EPC Ltd and AQUA, Ltd. Report for Local Government Engineering Department and World Bank.

[11] McArthur, J.M., Ravenscroft, P., Safiullah, S., Thirlwall, M.F., 2001. Arsenic in groundwater: testing pollution mechanisms for aquifers in Bangladesh. Water Resour. Res. 37, 109-117. Mercado, A., 1985. The use of hydrogeochemical patterns in carbonate sand and sandstone aquifers to identify intrusion and flushing of saline water. Ground Water 23, 635-645.

[12] Morgan, J.P., McIntire, W.G., 1959. Quaternary geology of the Bengal Basin, East Pakistan and India. Geol. Soc. Am. Bull. 70, 319-342.

[13] MPO, 1987. Groundwater Resources of Bangladesh. Technical Report Nr 5. Master Plan Organisation. Dhaka. Harza

[14] Nickson, R., McArthur, J., Burgess, W., Ahmed, K.M., Ravenscroft, P., Rahman, M., 1998. As poisoning of Bangladesh groundwater. Nature 395, 338.

[15] Nickson, R.T., McArthur, J.M., Ravenscroft, P., Burgess, W.S., Ahmed, K.M., 2000. Mechanism of arsenic poisoning of groundwater in Bangladesh and West Bengal. Appl. Geochem. 15, 403-413.

[16] PDO-ICZM, 2002, Inventory of Projects \& Initiatives in the Coastal Zone, Working Paper, WARPO, Ministry of Water Resources, Dhaka.

[17] Rahman, M., Hassan, M.Q., Islam, M.S., Shamsad, S.Z.K.M., 2000. Environmental impact assessment on water quality deterioration caused by the decreased Ganges outflow and saline water intrusion in southwestern Bangladesh. Environ. Geol. 40, 31-40.

[18] Ravenscroft, P., 2003. An Overview of the Hydrogeology of Bangladesh. In: Rahman, A.A., Ravenscroft, P. (Eds.), Groundwater Resources and Development in Bangladesh. Bangladesh Centre for Advanced Studies, University Press Ltd, Dhaka.

[19] Rus, J.S., 1985. Geohydrological Investigations in Khulna. DPHE Water Supply and Sanitation Projects. DPHE. Netherlands-Bangladesh Development Co-operation Programme.

[20] Shamsuddin, Sk. A.J., 1986, Water Supply in Coastal Region of Bangladesh, M.Sc. Thesis, Loughborough University of Technology, U.K.

[21] SRDI, 2001, Soil and Water Salinity in the Coastal Area of Bangladesh. Soil Resource

[22] Development Institute, Ministry of Agriculture, Dhaka, 2001.

[23] Umitsu, M., 1993. Late Quaternary sedimentary environments and landforms in the Ganges Delta. Sed. Geol. 83, 177-186.

[24] www.sdnpbd.org/river_basin/bangladesh/bangladesh_salinity_intrusion.htm 